MAIA, Andréa Casa Nova. Outro inferno de Dante numa mina de ouro na época de Vargas: Nova Lima, Minas Gerais. História, Ciências, Saúde-Manguinhos. Rio de Janeiro, v.21, n.4, out.-dez. 2014, p.1197-1214.

\title{
Outro inferno de Dante numa mina de ouro na época de Vargas: Nova Lima, Minas Gerais
}

\section{Another Dante's inferno in a gold mine during the Vargas era: Nova Lima, Minas Gerais}

Andréa Casa Nova Maia

Professora, Instituto de História/Universidade Federal do Rio de Janeiro. Largo de São Francisco, 1/201 20051-070 - Rio de Janeiro - RJ - Brasil andreacn.bh@gmail.com

\section{Resumo}

O artigo analisa as estratégias de controle existentes no trabalho na mina de Morro Velho, Minas Gerais, e as mudanças resultantes da implementação da legislação trabalhista durante o governo Vargas. Discute as doenças causadas pelo trabalho na mina, silicose e arsenicismo, através de depoimentos de ex-mineiros e do livro de um autor anônimo que aborda as doenças e as relações de poder entre patrões e empregados, apontando os limites da legislação e das lutas operárias. O livro traz um depoimento contundente de como a empresa proprietária, inglesa, burlou, durante muito tempo, leis como a da taxa de insalubridade. Direito que outras mineradoras, não só de propriedade inglesa, costumavam e até hoje costumam desrespeitar pelo mundo.

Palavras-chave: memória operária; Getúlio Vargas (1882-1954); doenças do trabalho; mina de Morro Velho; história de Minas Gerais.

\section{Abstract}

This article analyzes the control strategies in place at Morro Velho mine in the Brazilian state of Minas Gerais, and the changes after the implementation of labor legislation during the Vargas administration. The diseases common amongst mine workers, silicosis and arsenicosis, are investigated through statements given by former miners and a book by an anonymous author that discusses the diseases and the power relations between employers and employees, identifying the limitations of the legislation and the workers' struggles. The book presents a striking story of how for many years the British company side-stepped laws such as the insalubrity premium, a right which other mining companies, not only of British ownership, flouted and still flout in different parts of the world.

Keywords: workers' memory; Getúlio Vargas (1882-1954); occupational diseases; Morro Velho mine; history of Minas Gerais. 
$\mathrm{N}$ ova Lima, Minas Gerais. Em 1867, Richard Burton e sua esposa, Isabel, visitaram Morro Velho. Ela desceu dentro de uma caçamba até os recônditos escuros da mina. Nessas galerias, quase sem ar e com temperaturas altíssimas e muita umidade, os negros trabalhavam amarrados e dependurados por correntes, manejando alavancas. Lady Burton comparou Morro Velho ao inferno de Dante.

De meados do século XIX até os anos 1930 pouca coisa havia mudado em Morro Velho, apesar do fim da escravidão. Aliás, mesmo ao longo do século XX, a história da mina é marcada por constantes conflitos trabalhistas. Nada muito diferente do que podemos ler num romance como Germinal, de Émile Zola, ou, certamente, na própria historiografia social do trabalho, em que, em diferentes países, narra-se uma história comum de luta por direitos e, no caso do trabalho em minas, de lutas também por direitos relacionados às doenças causadas por esse tipo de trabalho. ${ }^{1}$

Depois de passar por vários donos, a mina de Morro Velho, que já foi a mais extensa do mundo e uma das mais antigas do Brasil, é hoje propriedade da AngloGold. Em 2009, época da desativação, a empresa devia indenizações pela insalubridade das condições de trabalho a 3.077 funcionários empregados nas décadas de 1970 e 1980. Muitos atingidos pela silicose faleceram sem o recebimento das indenizações. A questão das lutas trabalhistas se confunde com a história dos trabalhadores e de suas famílias e, aqui, nos preocupamos em analisar as condições de trabalho dos mineiros na época de Vargas, procurando perceber as mudanças ocorridas na relação entre patrão (inglês) e empregado (mineiro) quando da implementação da legislação trabalhista de Vargas. ${ }^{2}$

\section{A mina de Morro Velho antes e depois de Vargas}

Isso era a Morro Velho antes das leis trabalhistas de Getúlio Vargas. Até $34 \ldots$ era assim. Depois então, que organizados os sindicatos, as coisas mudaram, o trabalhador passou a ter direitos. Mas, antes disso, era uma verdadeira escravidão.

Waldir dos Santos

A questão das relações de poder dentro da mina de Morro Velho, local de trabalho da maioria dos empregados da mineradora, pode ser analisada sob dois aspectos. O primeiro, em que se coloca em evidência a violência com que os patrões de mina tratavam os mineiros, como se dava o controle do tempo, da atividade, da maneira de ser, dos discursos, do corpo, dos gestos. E um segundo, em que irão aparecer as antidisciplinas. Priorizaremos neste artigo o primeiro aspecto. ${ }^{3}$

Relatos de ex-operários se mostram reveladores de alguns dos mecanismos do forte sistema de repressão armado no interior da mina nos anos 1930. Aqui, estamos em sintonia com as novas formas de abordagem da história, nos baseando nos pressupostos teórico-metodológicos da história oral, pois, como bem salientou Marieta de Moraes Ferreira (2001, p.16).

A história interessou-se pela 'oralidade' na medida em que ela permite obter e desenvolver conhecimentos novos e fundamentar análises históricas com base na criação de fontes inéditas ou novas. ... A consideração do âmbito subjetivo da experiência 
humana é a parte central do trabalho desse método de pesquisa histórica, cujo propósito incluiu a ampliação, no nível social, da categoria de produção dos conhecimentos históricos, pelo que também se identifica e solidariza com muitos dos princípios da tão discutida 'história popular'.

A riqueza dos depoimentos permite vislumbrar questões referentes ao controle do tempo, da atividade e, para além do espaço de trabalho, possibilita compreendermos a condição de vida dos mineiros. Neles se pode observar a questão do controle da atividade e do corpo:

Como as pessoas fazem para aceitar esse tipo de serviço lá nesse fundo de mina? Bem, tinha um chefe, atrás, tinha uma vigilância, quem não trabalhasse a contento podia ser mandado embora. A hierarquia era o seguinte: tinha o chamado 'capitão de mina', que era normalmente um inglês, e depois os 'patrões de mina', que eram os encarregados gerais... Tinham espanhóis, italianos, os patrões de mina, os fiscais, os feitores e os arrancadores de choco, era a hierarquia. Era uma vigilância constante. ${ }^{4}$

O senhor Waldir dos Santos, em certo momento de sua entrevista, me contou que:

Tinha lá um chamado Capitão do Chapéu, um inglês. Ele só andava com o chapéu enterrado na cabeça, montado numa besta. Esse Capitão do Chapéu tinha uma besta que ele escolheu a mão, enorme. Um animal bonito. E ele andava com uma tala. Tala é uma espécie de cassetete de couro cru, para bater no animal. Machuca mesmo. Ele entrava com isso dentro da mina, de bota, vestido a caráter. E quando encontrava algum operário cochilando, por exemplo, ele metia a tala no operário. Batia mesmo. Era uma verdadeira escravidão. O camarada que reagisse, ele mandava embora direto, quando não mandava os capangas... ${ }^{5}$

Também o senhor Gentil Lúcio de Jesus, outro entrevistado, se lembrou do Capitão Chapéu. Ele era um dos protegidos do capitão, mas, mesmo assim, deixa claro em sua entrevista como todos morriam de medo do Chapéu:

O capitão Chapéu era o chefe geral da Morro Velho. Chapéu e Mão de Gancho. O Mão de Gancho é que era o chefe. O Chapéu era o segundo depois do Mão de Gancho. Ele tinha uma mão só. A outra mão era de prata. E ele é quem mandava. Quando ele entrava na mina, parava a mina. Nego tremia de medo dele. No tempo da tropa, aqueles tropeiros todos: - Olha, o Chapéu vem aí com o Mão de Gancho...

Paravam os burros todos para ele poder passar... Não tinha bonde, não tinha nada. Ele entrava com uma tala e se bobeasse ele batia. ${ }^{6}$

A empresa, em vez de utilizar novos procedimentos técnicos para aumentar o ritmo de produção e elevar sua taxa de exploração do ouro, o fazia por meio de seus patrões de mina e feitores, valendo-se de estímulos culturais e, quando preciso, de coerção física. Para tanto, "a figura central era o feitor" (Grossi, 1981b, p.60). O uso da violência corporal contribuía para "adestramento do corpo", mas, principalmente, para servir de exemplo aos outros mineiros, para reforçar a estrutura de produção. Não se podia parar para descansar dentro da mina, pois isso diminuiria a extração do ouro e, por conseguinte, o lucro da empresa. Os micropoderes se estendiam por todos os lados, e o feitor estava imbricado nesse processo. "Em Morro Velho, um feitor era como um capataz. Recebia tarefa de fazer encher tantos carros e não havia como negociá-la; era questão de produção e a Companhia não abria mão. Sobre 
o feitor pendia a ameaça de ser rebaixado a 'pá', caso não executasse bem o seu trabalho. Para defender o cargo, os feitores exigiam o máximo dos colegas, pois também viviam sob a 'chibata do capitão'" (Grossi, 1981b, p.61).

Não só os feitores, mas os outros mineiros também vigiavam e controlavam o trabalho alheio. Por exemplo, havia as chacotas dirigidas àqueles que não conseguiam terminar o trabalho em virtude das terríveis condições vivenciadas no interior da mina: "Se a pessoa não fosse muito forte saía de lá carregado. Quando o sujeito saía machucado, todo mundo reverenciava, era de certa forma herói... mas quando ele saía sambado, porque não resistiu ao calor, ao peso do trabalho, era ridicularizado pelos próprios companheiros, era o 'Sá Maria', um sujeito fraco - de acordo com o relato do operário Dazinho" (Le Ven, 1998, p.61).

Até o início do século XX, como se pode observar, a tala, no lugar do chicote que era usado para os escravos, era um instrumento de castigo que acabava por possuir um fim pedagógico de reafirmação constante do poder do inglês. A hierarquia da organização do trabalho reforçava os mecanismos de disciplinarização e fortalecia a rede do poder. Havia o capitão geral, que tinha como auxiliar um segundo capitão. Esse capitão geral é o mesmo citado pelo senhor Waldir dos Santos e pelo senhor Gentil Lúcio de Jesus. No princípio da década de 1930, o capitão geral era apelidado de "o Chapéu", por ser o único inglês que fazia uso dessa indumentária no subsolo. De acordo com Grossi, a "autoridade que emanava de sua pessoa era uma ameaça constante aos mineiros, que viviam aterrorizados com a perspectiva de desemprego quando a produção não seguia o ritmo das exigências patronais, e a oferta de trabalho era abundante. Quando qualquer dos mineiros notava a chegada do capitão, gritava para os colegas: 'Cuidado! Aí vem o Chapéu'” (Grossi, 1981b, p.53).

Foucault (1995) aponta para essa vigilância hierárquica em seu capítulo 2 de Vigiar e punir, intitulado Os recursos para o bom adestramento. Além de chamar atenção para a hierarquia da disciplina, ele também acaba por colocar o leitor a par da relação entre a vigilância e as necessidades da produção capitalista.

A vigilância torna-se um operador econômico decisivo, na medida em que é ao mesmo tempo uma peça interna no aparelho de produção e uma engrenagem específica do poder disciplinar. O próprio Marx já havia trazido à tona esta questão ao nos dizer que "Essa função de vigilância, de direção e de mediação torna-se a função do capital, assim que o trabalho que lhe é subordinado se torna cooperativo, e como função capitalista ela adquire características especiais (Foucault, 1995, p.203).

Foucault (1995, p.157) também destaca a função do vigiar no processo de produção capitalista. Localiza esse novo tipo de vigilância historicamente a partir do século XVIII, na Europa, e diz que era

diferente do que se realizava nos regimes das manufaturas do exterior pelos inspetores, encarregados de fazer aplicar os regulamentos; trata-se agora de um controle intenso, contínuo; corre ao longo de todo o processo de trabalho; não se efetua - ou não só - sobre a produção (natureza, quantidade de matérias-primas, tipo de instrumentos utilizados, dimensões e qualidades dos produtos), mas leva em conta a atividade dos homens, seu conhecimento técnico, a maneira de fazê-lo, sua rapidez, seu zelo, seu comportamento. ... À medida que o aparelho de produção se torna mais importante $\mathrm{e}$ mais complexo, à medida que aumentam o número de operários e a divisão do trabalho, 
as tarefas de controle se fazem mais necessárias e mais difíceis. Vigiar torna-se então uma função definida, mas deve fazer parte integrante do processo de produção; deve duplicá-lo em todo o seu comprimento. Um pessoal especializado torna-se indispensável, constantemente presente e distinto dos operários.

Na mina de Morro Velho, além do capitão geral, havia três capitães de terno, com seus respectivos segundos capitães de terno, e um capitão de poços e túneis. De acordo com o ex-operário Dazinho em entrevista (Le Ven, 1998, p.63):

Era uma hierarquia que era exercida com muita pressão mesmo, porque escolhiam as pessoas de pior reputação para colocar de encarregado (risos). Tanto que para ser encarregado lá, quer dizer anteriormente, porque depois eles foram abrindo para pessoas mais esclarecidas, mas, no início, o sujeito tinha que ter um bom porte físico, uma boa dose de ignorância (risos) para poder se transformar em arrancador de choco, em um patrão, em um fiscal.

Tratava-se de um escalão ligado à forma de trabalho por ternos (turnos). A Mina Grande funcionava com três turnos de turmas de trabalhadores, alternando-se semanalmente, de acordo com o seguinte horário: das 6 às 14 horas, das 14 às 22 horas e das 22 às 6 horas. Àqueles capitães cabia a fiscalização de cada turno respectivamente. Com relação ao controle do tempo, outra manifestação dessa problemática da microfísica do poder que remete à disciplinarização e à vigilância, pode-se citar outro momento da fala de um dos operários entrevistados, o senhor Waldir dos Santos, que comenta os turnos de trabalho dentro da mina:

Mas eu sofri muito. Eu chegava a chorar de tanto trabalho. Às vezes, vinha aquele minério, pois eles aproveitavam, depois que a areia ia até no galo onde tiravam, o minério para fazer arsênico. Havia fábrica de arsênico. Dali voltava aquela areia outra vez. Jogavam tudo dentro do silo, para apurar tudo. E essa areia já vinha úmida e formava uma massa dura, parecendo cimento, como concreto. Você batia e não saía. E havia umas pás com cabo longo, resistente. Então você ficava ali batendo com aquelas pás. Às vezes saía até fogo. E nessa máquina, de vez em quando, batia ferro contra ferro e o feitor chegava. Às vezes até batia nos meninos... Eram meninos, meninos, adolescentes assim como eu, 14, 16 anos... Um sofrimento. Trabalhava-se de três turnos. Um turno entrava às 6 da manhã, saía às 2 horas da tarde. Outro turno entrava às 2 horas da tarde e saía às 10 horas da noite. E, outro turno, entrava às 10 horas da noite e saía às 6 horas da manhã. Cada semana eu trabalhava em um turno diferente. Por exemplo, hoje, segunda-feira, entrava no turno das 6 horas da manhã. Até sábado eu trabalhava saindo às 2 horas da tarde. Na semana seguinte, eu entrava às 2 horas da tarde e saía às 10 horas da noite e, assim, íamos revezando... E quando aquela turma estava, pela manhã, das 6 às 2 , no domingo ela dobrava. Fazia de 6 horas da manhã às 6 horas da tarde. $\mathrm{E}$ a turma que estava de 2 horas às 10 horas da noite, fazia das 6 horas da tarde às 6 horas da manhã. Não adiantava reclamar. Não tinha lei. Quem reclamasse era mandado embora. Sem direito a nada e pronto. Eles faziam o que eles queriam. ${ }^{7}$

Nota-se, nesse depoimento, a menção a outro funcionário encarregado da vigilância que já havia sido citado: o feitor. O feitor era responsável pela fiscalização do trabalho no realce e de "limpar o choco", no que era auxiliado pelo choqueiro ou arrancador de choco. ${ }^{8}$ Além do feitor havia o patrão, encarregado de velar pelos realces daquele "stop". Sua função consistia em escalar os trabalhadores de realce, cuja mobilidade horizontal variava de acordo 
com as necessidades e possibilidades de extração. "Nenhum interesse particular do operário era considerado. A não obediência à escala era punida com ameaça de dispensa ou sua efetivação. A submissão às ordens era exigida de modo irrestrito, ignorando-se qualquer grau de condescendência com os subordinados" (Grossi, 1981b, p.54). Nessa hierarquia, o último elemento a ser considerado, o subordinado, era o "carreiro", "homem da pá", ou simplesmente "pazeiro". Possuía, sob a ordem do feitor, a tarefa de encher as vagonetas de minério, retirá-las do realce e calçar a mina com terra e lapa, que vinham da superfície. Enquanto os carreiros enchiam as vagonetas, outros as empurravam. Grossi faz uma observação em relação ao poder desses operários que, sendo os últimos na hierarquia das funções organizadas pela empresa no subsolo, só exerciam poder sobre o objeto de seu trabalho: o minério.

O camarada era atacado pela doença da silicose, ${ }^{9}$ espécie de tuberculose provocada pelo pó de minério no pulmão. Adoecia, mandavam ele embora e ele morria, só que nada acontecia. Muita gente morria. Além dos acidentes de trabalho, que ocorriam toda semana. Morriam dezenas de homens. Dentro da mina de ouro, eles perfuravam a rocha toda com brocas para enfiar as bananas de dinamite. Em seguida, eles saíam da área de risco e acionavam o mecanismo detonador, do lado de fora da mina. Só que muitas vezes falhava uma das bananas de dinamite, nem todas explodiam. Quando, em outra ocasião, sem querer, um dos operários batia com a pá numa dinamite que não havia sido detonada, esta explodia e pegava a turma toda lá trabalhando. Arrebentava tudo. Os homens saíam aos pedaços, saíam no saco. Tinham que recolher pedaços de operários no saco. Era terrível. Isso era terrível. Toda semana eram dezenas. Só depois de Getúlio é que as coisas começaram a melhorar.... O Galo tinha um forno para queimar o minério e apurar o arsênico. O negócio era tão violento que o morro não tinha mato. Em volta desse forno de queimar minério para arsênico não nascia nada. Muito veneno. Envenenavam muita gente. O povo que trabalhava lá. Não tinha índice de periculosidade nem nada. Os que trabalhavam lá, se morriam, acabou. Colocavam outro no lugar. E eles não tinham nem noção do perigo. Mesmo que tivessem, precisavam trabalhar. Era uma coisa muito terrível, mesmo. ${ }^{10}$

O castigo físico e o controle do tempo não eram os únicos dispositivos de coerção incluídos na "economia" do poder inglês sobre seus operários brasileiros. Tal mecânica da dominação inglesa não era exercida apenas pelo castigo, mas se estendia também para o controle da alimentação, do vestuário etc.

No que diz respeito à alimentação, por exemplo, desde o século XIX existia em Nova Lima a Casa Aristides, de propriedade do coronel Aristides, um empório comercial com dezenas de funcionários, refeitório no próprio local de funcionamento, capacidade de fornecer toda espécie de mercadorias necessárias aos habitantes da cidade, incluídos os ingleses, além de ser casa importadora.

No século XX, guardou suas características de armazém capaz de atender às necessidades vitais dos mineiros. Após o desastre de 1886, quando a mina paralisou suas atividades à espera de uma decisão de Londres sobre o destino do empreendimento, a Casa Aristides financiou as despesas dos funcionários, incluindo empréstimos financeiros.

Posteriormente à reabertura da mina, a Casa Aristides passou a fornecer mercadorias aos mineiros mediante desconto em folha. A companhia fornecia o teto de crédito a que cada trabalhador teria direito, o que permitia ao armazém controlar o "fiado" (Grossi, 1981b, p.73). 
Nesse sentido, nota-se claramente o controle dos ingleses sobre a alimentação dos operários. A Casa Aristides representava uma camisa de força, pois não lhes dava a oportunidade de comprar em outros lugares que vendessem mais barato. $\mathrm{E}$, ao mesmo tempo, devido às dificuldades financeiras, obrigava-os a aceitar as cadernetas como garantia do "fiado". Essa imposição da empresa, prática comum entre as companhias de mineração, submetia coercivamente a classe trabalhadora sob a forma tradicional de troca indireta de mercadorias mediada pela caderneta. O endividamento na Casa Aristides passou a ser um mecanismo de controle coativo. De acordo com Grossi (1981b, p.74), "para a família do mineiro, a caderneta representava a segurança de alimentação durante o mês, dentro do quadro de sua penúria. Mas, por outro lado, era um dilema: utilizar a caderneta barrava a oportunidade de aquisição de mercadorias a preços mais acessíveis" .

O senhor Waldir também se lembra da Casa Aristides, mas é o senhor Gentil quem explicitará melhor, em sua narrativa, as amarras em que o operário e sua família se viam presos. De acordo com o ex-mineiro, quando alguém adoecia e era mandado para o hospital, a família podia adquirir os produtos necessários na Casa Aristides, mas quando o operário saía do hospital seu salário já ia diretamente para as mãos do comerciante e ele só recebia o troco, quando havia: "tinha a Casa Aristides que fornecia para o operário... para a família enquanto ele estivesse doente... o dia que ele tivesse alta para ir trabalhar, a Morro Velho descontava tudo... aquilo que o armazém despachou para a família... a Morro Velho descontava e dava algum troco se sobrasse... e nunca sobrava mesmo". ${ }^{11}$

Outra imagem que Foucault (1995) discute e que se apresenta relevante na tentativa de analisar o cotidiano dos operários de Morro Velho diz respeito ao panóptico. O panoptismo trabalhado por esse autor, lugar da inspeção constante, do olhar alerta que está por toda parte, também existia no local de trabalho desses mineiros. De acordo com o autor, o panóptico funciona como uma espécie de laboratório de poder: "Graças a seus mecanismos de observação, ganha em eficácia e em capacidade de penetração no comportamento dos homens; um aumento de saber vem se implantar em todas as frentes do poder, descobrindo objetos que devem ser conhecidos em todas as superfícies onde este se exerça" (p.180).

Ele servia para fiscalizar os operários. No caso da mina, para que os ingleses se certificassem de que os mineiros não estavam roubando o ouro. Esse controle pelo olhar do outro não se dava apenas em relação aos operários, mas também a outros indivíduos que, vez por outra, iam visitar a mina, conforme explica o "contador de histórias", senhor Waldir dos Santos:

Quando voltamos para Nova Lima, fomos morar na casa da minha tia, irmã da minha mãe. Chamava-se Maria e tinha o apelido de Bia, e casada com Laurindo. Laurindo era patrão no sistema de apuração. Era um daqueles que tomava conta, ficava olhando do alto quem é que estava tentando roubar alguma coisa, para não deixar. Que eles tinham aqueles ângulos que os ingleses e esses patrões ficavam para poder vigiar alguém que tivesse tentando roubar. E era uma tentação. ... Os ingleses e os patrões vigiavam a saída dos camaradas, principalmente dos que lidassem mais com o ouro, que não fosse minério pobre ou ainda por apurar. Os operários eram revistados totalmente antes de sair. Porque eles trabalhavam na fundição e em todo local que havia acesso ao ouro, todos eram muito fiscalizados. Fiscalizavam até os visitantes. ${ }^{12}$ 
Importante retomar, nesse sentido, a questão do controle do tempo e da atividade. O do controle do horário é, de acordo com Foucault, uma velha herança das comunidades monásticas. Segundo o autor, o rigor do tempo industrial guardou durante muito tempo uma postura religiosa:

no século XVII, o regulamento das grandes manufaturas precisava os exercícios que deviam escandir o trabalho ... mas ainda no século XIX, quando, se quiser utilizar populações rurais na indústria, será necessário apelar a congregações, para acostumálas ao trabalho em oficinas; os operários são enquadrados em 'fábricas-conventos'. ... Durante séculos, as ordens religiosas foram mestras de disciplina: eram os especialistas do tempo, grandes técnicos do ritmo e das atividades regulares (Foucault, 1995, p.137). ${ }^{13}$

A questão do controle do tempo expressa uma preocupação com a qualidade desse tempo, acompanhada por controle ininterrupto, pressão dos fiscais, anulação de tudo que possa perturbar e distrair; trata-se de constituir um tempo integralmente útil. Como no Projet de règlement pour la fabrique d'Amboise, exemplo utilizado por Foucault, também na mina de Morro Velho era expressamente proibido, durante o trabalho, divertir os companheiros com gestos ou fazer brincadeiras, comer, dormir, conversar ou contar histórias que distraíssem o operário de seu trabalho. E, mesmo que se quisesse, o barulho ensurdecedor das mãos de pilão batendo dia e noite não permitia interações desse tipo.

Pelo que indica a fala do senhor Waldir dos Santos, contudo, tal preceito não era seguido ao pé da letra. Havia certa resistência ao processo de vigilância e disciplinarização, pelo menos nesse sentido. Por isso, torna-se importante levar em conta um segundo aspecto, além desses processos produtores da disciplina, que é justamente o da antidisciplina. Michel de Certeau (1994, p.41) afirma que:

se é verdade que por toda parte se estende e se precisa a rede da 'vigilância', mais urgente ainda é descobrir como é que uma sociedade inteira não se reduz a ela: que procedimentos populares (também 'minúsculos' e cotidianos) jogam com os mecanismos da disciplina e não se conformam com ela a não ser para alterá-los; enfim, que 'maneiras de fazer' formam a contrapartida, do lado dos consumidores (ou dominados?) dos processos mudos que organizam a ordenação sociopolítica.

Esses procedimentos populares também podem ser observados pelos relatos dos entrevistados. Eram gestos dissimulados, conversas em código, apelidos dentro do discurso dos operários que demonstram, em certo aspecto, essa antidisciplina discutida por Certeau. Além disso, fora da mina, na vila operária e nos arredores da empresa, notam-se outras "maneiras de fazer" nem tão minúsculas, porém também com um conteúdo antidisciplinar subjacente.

A antidisciplina estava presente dentro da mina na maneira como os operários chamavam os ingleses: "Tinha o Sam Bunda Molhada... Era o chefe da fundição de ouro. Porque todo mundo lá tinha apelido... e ele sempre tinha a bunda molhada... Um bundão sempre molhado. Ele dessorava suor pelo ânus... E então eles deram o apelido dele de Sam Bunda Molhada", contou o senhor Waldir. Ou: "Naquele tempo era um tal de Quebra-coco... o nome dele era Sanders, mas nós chamávamos ele de Quebra-coco. Todos os ingleses, todo mundo tinha um apelido", disse o senhor Gentil. ${ }^{14}$

$\mathrm{Na}$ maneira de fazer-se comunicar durante o trabalho, gestos e códigos próprios eram utilizados, mesmo com a poluição sonora e a vigilância constante dos "patrões de mina": 
Era um barulho ensurdecedor. Aquelas mãos de pilão batendo dia e noite, não paravam. Só parava na Sexta-Feira da Paixão ou no dia 24 de junho, que era o dia da festa da companhia. Eram os únicos dois dias do ano em que parava o serviço na Morro Velho. Era gravíssimo. Onde eu trabalhava tinha que pôr um chumaço de estopa do ouvido, e a uma distância de meio metro, aliás, nem falando no ouvido você me ouvia. Nós nos comunicávamos por gestos, como surdo-mudo. Nos comunicávamos por um sistema que eles mesmo criaram para comunicação a distância. Eles contavam a distância o filme que eles tinham visto no cinema. Você contava o enredo dele todo para o camarada e ele te entendia por gesto. ${ }^{15}$

Os exemplos dizem respeito às "maneiras de fazer" desses operários dentro da mina. Vamos agora pensar a relação entre os operários da mina de Morro Velho e o "mito" Getúlio Vargas.

\section{As leis trabalhistas e as lutas do sindicato da Morro Velho}

Ao que tudo indica, nas lutas dos operários durante as negociações com os patrões ingleses, a presença do Estado, por meio da promulgação de leis de amparo ao trabalhador, é fator importante a ser considerado. Pode-se inferir que o governo Vargas influenciou, em certa medida, o comportamento dos operários em relação à empresa, reforçando sua mobilização pela aplicação da lei getulista.

Houve, sem dúvida, conquistas sociais dos trabalhadores, mas elas contaram com o apoio de leis que beneficiaram, mesmo que com inúmeras restrições, os operários da mina. $\mathrm{O}$ Estado, através da ação do Ministério do Trabalho, incorporou as reivindicações operárias e também as reivindicações patronais de limite às ações operárias, o que fez parte da estratégia autoritária. Porém, no caso da Morro Velho, as reivindicações dos operários foram pautadas no cumprimento da legislação trabalhista. A própria fundação do sindicato, primeira conquista dos operários da mina, esteve associada, até certo ponto, à conjuntura do país. Como afirma Grossi (1981a, p.74), "a fundação do sindicato dos mineiros se inseriu no novo quadro institucional e constitucional que pervadiu a sociedade brasileira após o movimento armado de 1930, que finalizou a Primeira República". Como se observa, é fato que os trabalhadores da Morro Velho se apropriaram das concepções dominantes acerca do Estado paternalista para reivindicar sua eficiência. Nesse sentido, concorda-se aqui com a afirmação de Ferreira (1997, p.32-33):

As enunciações discursivas de trabalhadores e populares à época do primeiro governo de Vargas demonstram como eles aceitavam o discurso oficial e as concepções dominantes. Todavia, não interpretamos essas formas de expressão como conformismo, passividade ou resignação, mas, antes, como apropriação - no sentido dado por Roger Chartier -, que lhes permitia fazer leituras criativas, singulares e desviantes. $\mathrm{O}$ aparente conformismo fazia parte de uma estratégia de vida para alcançarem seus objetivos mais imediatos.

Sem dúvida, com a fundação do sindicato dos mineiros, começou uma nova fase para as relações trabalhistas na Morro Velho, com reivindicações aguerridas que, como já foi dito, na década de 1940 sofreram influência marcante do Partido Comunista. Nesse sentido, pode-se concluir que as décadas de 1930, 1940 e, indo além, a de 1950 foram marcadas por grandes mudanças no ambiente político-social, com a implementação das leis trabalhistas de Vargas, 
o que se refletiu diretamente nas relações de trabalho. O movimento sindical ganhou corpo, a Consolidação das Leis Trabalhistas (CLT) foi promulgada e, nesse entrecruzamento das lutas operárias com as políticas governamentais de concessão de benefícios ao trabalhador, a realidade do trabalho na mina de Morro Velho mudou consideravelmente, melhorando em diversos aspectos. A empresa, contudo, resistiu às mudanças e manteve alguns padrões de exploração já consolidados.

\section{A "política" da empresa}

Roberto Costa, um autor da época cujos únicos dados biográficos conhecidos são os que o próprio escreveu na introdução de seu livro - subsídio para a análise aqui empreendida escrito na prisão e publicado em 1955, narra que, em 1947, a Companhia decidiu despedir 51 operários que se vinham destacando como lideranças sindicais: "Tratando-se, porém, de empregados com mais de 10 anos e, portanto, 'com estabilidade assegurada pelas Leis Trabalhistas', somente poderiam ser despedidos à base de denúncias graves e comprovadas, surgindo então a ideia genial - digna de um Churchill - de que eram... sabotadores" (Costa, 1955, p.31; destaque meu).

Assim, conforme o trecho citado sugere, pode-se inferir que muitas eram as estratégias da empresa para não garantir aos operários os direitos expressos nas leis getulistas. O mesmo autor conta - ainda na época em que escreveu A cortina de ouro (1955) - que a empresa sempre dava um jeito de disfarçar seus lucros reais, para continuar negando-se a garantir melhores condições de trabalho aos operários. O senhor Gentil, apesar de ter sempre gostado dos ingleses, afirma que: "Toda a vida a Morro Velho pagou pouco, toda a vida... nunca teve jeito de ganhar bem... E tirava tanto... Era ouro mesmo... O ouro da Morro Velho era mandado para o Rio. ... Eles davam a nota que eles queriam dar... Tiravam lá arrobas de ouro e davam conta de uns quilos... Tirava lá e levava para o Rio e lá eles faziam o que queriam... falavam que não estava dando nada...". ${ }^{16}$

Energicamente, afirma Roberto C. Costa (1955, p.32; destaque no original): "Na ocasião oportuna mostraremos ainda que essa política de baixa produção de suas minas tem sido a arma - chantagem - utilizada pela poderosa empresa para conseguir favores do governo, manter salários baixos dos seus operários e eximir-se de responsabilidades, como é o presente caso em que se nega a pagar a 'taxa de insalubridade' e ameaça fechar suas minas, lançando ao desemprego milhares de trabalhadores".

O mesmo autor denuncia ainda outra vez o descompasso entre as leis de Getúlio e seu cumprimento pela companhia inglesa:

Mas continuamos a ouvir periodicamente a cantilena de miséria com que tem ludibriado a opinião brasileira, obtido isenção total de impostos, manutenção de taxas de salário abaixo do mínimo, 'deixando de cumprir as leis brasileiras', como é o caso atual da 'taxa de insalubridade', ameaçando (quando pode) mendigando, subornando, e mantendo a Cortina de Ouro com que oculta todos os fatos que denunciamos e outros... (Costa, 1955, p.37; primeiro destaque meu, segundo destaque no original).

Ao que tudo indica, apenas parte dessas "leis brasileiras" referidas pelo autor foram cumpridas. Mas vale ainda ressaltar o valor histórico do trabalho de Roberto Costa que, enquanto 
livro de época, constituindo-se em rica fonte documental, é bastante esclarecedor da diferença entre o que era exigido por lei e o que era a realidade, tratando-se das condições de trabalho na mina de Morro Velho. Essa questão também aparece em outras regiões e nas relações de trabalho entre patrões e empregados em outras empresas.

De acordo com Robert Levine (1983) isso se explicava pelo fato de que o texto das leis trabalhistas, em alguns itens, não era suficientemente claro, dando margem a que as empresas não cumprissem a lei em sua integralidade. Segundo o autor: "No entanto, a linguagem legal era cheia de brechas e os patrões encontravam meios de burlar os regulamentos até mesmo debaixo dos olhos atentos da ampliada burocracia federal" (p.315).

\section{“Vida - paixão e morte dos operários": a silicose e o arsenicismo, os pós que matavam}

É no quarto capítulo de seu livro que Roberto C. Costa se dedica à narrativa das condições de vida dos operários da Morro Velho. O capítulo, intitulado "Vida - paixão e morte dos operários" apresenta as condições de trabalho dos operários nos idos de 1930 e 1940, até meados da década de 1950, ou seja, antes, durante e depois da Consolidação das Leis Trabalhistas.

Conforme apresentado pelos depoentes, em particular o senhor Waldir dos Santos, em algumas minas, como no "Galo", o minério continha arsênico, com uma fábrica de produção dessa substância em Nova Lima. O arsênico é responsável por uma doença grave, o arsenicismo. Segundo um relatório do Serviço Médico da Divisão do Fomento da Produção Mineral (Serviço..., 1943), órgão do governo, em “135 operários examinados 117 apresentavam lesões produzidas pela doença", manifestações que surgiam, na maioria dos casos, com apenas quatro meses de trabalho, inutilizando praticamente as vítimas. $\mathrm{O}$ arsenicismo provocava nos operários dores muito fortes nas articulações, além de deformações e úlceras.

Outra doença muito frequente nos operários da Morro Velho, principalmente nos mineiros, era a já mencionada silicose, que, até recentemente, atingia os trabalhadores da minas de Morro Velho, como, por exemplo, o senhor Gentil Lúcio de Jesus e o senhor Dazinho, ambos já falecidos. ${ }^{17}$ De acordo com o relatório de 1943 (Serviço..., 1943, p.87) - ano da promulgação do decreto-lei que formalizou a CLT - "nos exames procedidos em 908 mineiros, 304 (33,4\%) apresentam casos positivos de silicose".

Nova Lima era sacudida pela tosse. Essa expressão que ressalta as condições de saúde dos mineiros de Nova Lima aparece na explicação detalhada de Michel Le Ven (1998, p.62) sobre a tosse de Dazinho: "A entrevista foi pontuada de tosse, que além de encurtar a vida e a capacidade de respiração, é crônica, oca, ressoante, provocando sofrimento e angústia".

Essa também era a convicção de Hélio Pellegrino (citado em Le Ven, 1998, p.62-63), que assim se referiu à cidade de Nova Lima:

Nas noites de Nova Lima quando buscava repouso, a cidade era sacudida e inquietada por uma trovoada surda e cava que, nascendo dos casebres operários, rolava em ondas recorrentes até as fraldas das montanhas em torno. Era a grande tosse dos pobres, sintoma e denúncia da silicose que os roía. Os ingleses perturbados em seu sono e em sua boa consciência, ao invés de adotarem medidas hábeis para que a silicose cessasse, resolveram enfrentar o problema pelo exclusivo ataque ao sintoma. Montaram em Nova Lima, com banda de música e foguetes, uma fábrica de xarope contra tosse, 
que ao mesmo tempo produzia, para consumo dos colonizadores, matéria-prima de refrigerantes não encontrados no país...

Em 26 de agosto de 1938, quase um ano após o golpe que instituiu o Estado Novo, o engenheiro Octavio Barbosa apresentava ao Ministério da Agricultura o seu relatório como enviado especial do Departamento Nacional da Produção Mineral (Serviço..., 1943) com "Sugestões para regulamentação sobre a higiene do trabalho nas minas do Brasil", depois de estudar profundamente as minas da Morro Velho. Nele, mostrava o técnico as condições extremamente penosas e "letais" em que trabalhavam os operários da Morro Velho que, na época, ainda não possuíam sequer recursos elementares de higiene, trabalhando em condições "subumanas".

O relatório recomendava a exigência por lei da aplicação e emprego de maquinário moderno adequado e aparelhos indispensáveis, mundialmente conhecidos, usados em trabalhos idênticos.

De acordo com Anna Beatriz Almeida (2004), as leis de acidentes do trabalho de 1934 e de 1944, guardadas as suas diferenças, equipararam as doenças profissionais aos acidentes do trabalho e as dividiram em dois grupos: as ditas profissionais, inerentes ou peculiares a determinados ramos de atividade e as resultantes das condições especiais ou excepcionais em que o trabalho fosse realizado. Segundo a autora,

O primeiro grupo, as inerentes ou peculiares a determinados ramos de profissão, tais como as intoxicações por chumbo, a silicose, entre outras, constantes da relação elaborada pelo MTIC estariam isentas da necessidade de comprovação da ligação entre o trabalho e a doença. No segundo grupo, as doenças resultantes das condições do trabalho, no qual se incluem os casos de indenização por doenças como a tuberculose e hérnia, por exemplo, era necessário comprovar-se o nexo entre o trabalho e a deflagração da doença (Almeida, 2004, p.255).

No entanto, mesmo com a isenção da necessidade de comprovação da ligação entre o trabalho e a doença, o autor de A cortina de ouro foi enfático em sua denúncia: "Pois bem, o honesto e humano relatório se não foi destruído foi para o arquivo, pois, até hoje as condições de trabalho nas minas da Cia. Morro Velho continuam as mesmas e a empresa se nega até hoje a pagar a taxa de insalubridade - que pode sem exageros ser apodada de taxa de morte - de seus operários, as suas mais diretas e maiores vítimas (Costa, 1955, p.8).

Note-se que o livro terminou de ser escrito em julho de 1955, na cadeia do C. Q. da Força Policial do Estado de Minas Gerais. O autor foi preso, segundo seu prefácio, por haver incitado “o povo 'à depredação do consulado americano', no dia 24 de agosto, data que a História registra, coincidentalmente, como a da monstruosa matança dos huguenotes, genocídio até hoje sem réus porque a Justiça da época servia a Sua Majestade Católica da França" (Costa, 1955, p.8; destaque no original). E Costa prossegue, fazendo referência à morte de Getúlio Vargas: "Honesta e conscientemente, devo repartir tamanha glória com o povo brasileiro, que naquele gesto manifestou sua compreensão quanto à Carta de Getúlio, confirmando o que o mesmo profetizara anteriormente ao dizer: 'o povo um dia fará Justiça com as próprias mãos'” (p.8; destaque no original).

Percebe-se que autor do livro era simpatizante da "causa" getulista e chegou a ser preso na ocasião da morte de Vargas, 24 de agosto, quando, numa livre interpretação da carta- 
testamento de Getúlio, entendia que eram os norte-americanos os responsáveis pelo suicídio do presidente. O livro de denúncia contra a empresa inglesa passa também a ser uma luta contra o "imperialismo" das potências estrangeiras. Evidencia-se a tendência nacionalista do autor, que conjugava com os pressupostos nacionalistas de Vargas.

Mesmo com todo o ideário de defesa do nacionalismo e dos trabalhadores nacionais, nem Getúlio com suas leis trabalhistas, nem os operários com suas lutas sindicais parecem ter conseguido resolver, ainda na década de 1940, todos os problemas trabalhistas da mina. De acordo com Roberto Costa (1955, p.42),

Foi uma das suas vítimas [da silicose] o operário Francisco Soares de Oliveira, na sua obra: 'Os horrores das minas de Morro Velho', quem descreveu ao vivo as torturas de outro sofrimento dos operários, 'a caimbra' relatando o seguinte: "Com a extraordinária temperatura de cinquenta e tantos graus, tudo ali escalda, tudo queima! E aqueles desgraçados que, parecem, vão se fundir em água tanto é o suor que expelem, vão batendo... batendo... e o feitor gritando... gritando... e ao entrar e sair dos vagonetes, e a falta de ar para se respirar, aqueles infelizes, sofrendo a influência daquela temperatura de forno, entram num tormento indizível: o corpo vai se esquentando, se esquentando, as fontes latejam, a cabeça dói, como se quisesse arrebentar, as cadeiras reclamam descanso, o sangue ferve, os braços flacidam-se; o e o feitor, impassível e empertigado, grita: 'Quem não aguenta cai fora!... Aqui é pr'a quem pode!'” (destaque no original).

E, mais adiante:

Vencidos pela inclemência de uma atmosfera inabitável, onde só podem ficar impassíveis os seres inorgânicos, os miseráveis são violentamente atirados ao chão (pedra), por um indizível acesso nervoso, que lhes faz rebolcarem-se sobre o mineral, na mais horrorosa agitação convulsiva. Estes acessos tão célebres e comuns têm ali o nome de câimbra; mas essa palavra, câimbra, não tem propriedade para significar a natureza do estado mórbido que querem designar com ela. Câimbra, contração espasmódica dos nervos, não é bem o que ataca aos mineiros, em consequência do excesso de calor. $\mathrm{O}$ lastimoso estado mórbido que vitima os desgraçados escravos das minas de Morro Velho, que eu sofri, e vi sofrer a muitos dos meus irmãos de classe, não pode ser classificado de câimbra... porque essa classificação não traduz o horroroso aspecto do ataque que eu sofri, e vi sofrerem - pelo excesso de calor - a muitos companheiros de desgraça... (Costa, 1955, p.42-43).

Roberto C. Costa relata ainda as lutas operárias em Morro Velho. Ele demonstra como a Saint John Del Rey Mining Company subvertia as leis a seu bel-prazer, auxiliada por uma "casta de traidores". Juntos, empresa e subornados manobravam os três poderes do Estado Legislativo, Executivo e Judiciário:

um Estado dentro do Estado na mais completa plenitude de sua força, prepotente, arbitrário, cruel, opressor, aplicando sem peias a melhor denominação de um regime fascista no seu território, onde tudo quanto não era obrigatório era terminantemente proibido. ... Mas sua maior arma sempre foi e ainda é o ouro, com que compra consciências negociáveis, subverte leis, macula a verdade, ou obtém o silêncio sobre os seus crimes e falcatruas, ocultando com a sua 'Cortina de Ouro' as mazelas da sua formação e a manutenção dessa excrescência feudal no regime semifeudal em que ainda vivemos (Costa, 1955, p.56; destaque no original). 
Daí se obtém o título do livro: A cortina de ouro, porque oculta a realidade com subornos, seja para altos magistrados, seja para operários. Contra a força da empresa que, com seu ouro, comprava as pessoas, surge na narrativa a força da luta da classe operária, novos inconfidentes, que teriam como meta a libertação e emancipação não só dos operários, mas, nas palavras de Roberto Costa (1955, p.51), "ainda quando os operários da Cia. de Morro Velho lutam apenas pelo cumprimento de um dispositivo legal - como é a 'taxa de insalubridade' - essa luta extravasa as suas limitações e transpõe as fronteiras da batalha que se trava pela emancipação do Brasil do jugo dos latifundiários e grandes capitalistas ligados ao imperialismo norteamericano e sustentáculos do atual governo e regime, contrários ao desenvolvimento da sociedade e, portanto, fadados ao desaparecimento" (destaque no original).

Os trechos do livro A cortina de ouro permitem observar, mais uma vez, a relação existente entre lutas operárias em Nova Lima - Sindicato dos Mineiros de Morro Velho - e os dispositivos legais, propiciados pelas mudanças advindas da nova legislação criada ao longo do governo de Getúlio Vargas. O autor explicita claramente essa questão ao afirmar que os operários, naquele momento, lutavam simplesmente pelo cumprimento da lei trabalhista, no caso, a "taxa de insalubridade".

Aliás, ao destacar as principais lutas pelos seus direitos levadas a cabo pelo sindicato dos mineiros, mesmo com toda a intimidação, mesmo contra a vontade da St. John Del Rey Mining Co., vê-se que, praticamente, todas as lutas passavam pela conquista de direitos já adquiridos com a legislação trabalhista. São exemplos: a própria luta contra a atitude da empresa de não reconhecer o sindicato e de se negar a receber seus representantes; a luta contra a burla da lei dos 2/3; pelo pagamento da taxa de insalubridade (19 de dezembro de 1938); pela melhoria de condições de higiene e trabalho nas minas; contra o excesso de horas de trabalho que atingia até 12 horas diárias; pela melhoria da técnica na produção das minas; contra o perigo de intoxicações na redução do minério; contra as perseguições aos operários ligados ao sindicato; pelo pagamento do descanso semanal; pelo pagamento do salário mínimo (também uma criação do governo Vargas); pelo direito de greve assegurado pela Constituição; pelo exame médico anual; pela criação da caixa de pensões (outra garantia da nova legislação trabalhista); pela fundação da cooperativa dos operários; pela instalação de restaurante dos operários; e pela regulamentação do horário de trabalho das turmas, no cumprimento da lei de seis horas de trabalho nas minas.

Outro trecho do livro, finalizando a análise sobre o interessante capítulo de Roberto Costa e as pistas que vai revelando ao longo de sua narrativa acerca das lutas operárias em sintonia com o Ministério do Trabalho e com as leis trabalhistas de Getúlio Vargas, diz respeito, já em 1939 - auge do Estado Novo -, a uma extensa representação que o sindicato faz junto ao Ministério do Trabalho, na qual eram relatados todos os fatos e processos usados pela Morro Velho, denunciando que, dos trezentos ofícios e cartas dirigidos à empresa, o sindicato não havia recebido qualquer resposta. Outro indicador das relações trabalhador/sindicato Estado e Estado Novo da Era Vargas - empresa inglesa (St. John Del Rey Mining Company)

Apresentando as vitórias operárias, suas relações com as leis trabalhistas do Estado varguista e os limites de sua penetração real na mina de Morro Velho, ao longo das décadas de 1930 e 1940, o livro sugere que o saldo ainda é negativo. Ao que tudo indica, em se tratando de condições de trabalho na mina de Morro Velho, persistiu a ironia de um jornalista de 
O Debate (22 maio 1934, p.12), no ano da fundação do sindicato dos mineiros, que data de 13 de maio: "É Morro Velho - a atração dos viajantes, a citação do Estrangeiro - é lá que morre o Ministério do Trabalho!".

De acordo, porém, com livro editado pela companhia, hoje não mais sob o domínio inglês, a Mina Grande atingiu, já na década de 1940, 2.453m de profundidade, e foi instalada a planta de refrigeração no subsolo para melhoria das condições de trabalho. Os equipamentos de proteção individual também foram implantados, bem como as lanternas a bateria, em substituição aos lampiões de carbureto. Todas essas medidas permitiram melhorar a prevenção de acidentes no trabalho (Pires et al., 1995, p.113). Resta saber até que ponto essas melhorias foram resultado da política getulista combinada à grande luta dos trabalhadores através do movimento operário organizado.

Anna Beatriz Almeida (2004) cita um artigo interessante que talvez possa nos esclarecer ainda mais sobre as relações entre o capital, o trabalho, o Estado e a medicina brasileira. De acordo com a autora, a Revista Médica do Trabalho publicou na mesma época um artigo em que se descreviam as condições de trabalho na St. John del Rey Mining Company, no qual tem-se a impressão de que algumas das medidas apontadas por especialistas e técnicos como Hugo Firmeza já tinham sido implantadas em Morro Velho. O texto, segundo a autora, destacava as medidas relacionadas à moradia dos operários, à prevenção da silicose, aos cuidados com a ventilação nos ambientes de trabalho e a ações no campo da assistência médica e lazer. $\mathrm{O}$ artigo ressaltava o crescimento no Brasil de uma nova mentalidade com relação à defesa da saúde dos trabalhadores por parte dos empresários. A autora cita trecho em que se afirma:

Não somente os simples princípios de higiene geral que começam a preocupar os dirigentes das grandes empresas industriais. A prevenção das doenças profissionais através da neutralização dos métodos de trabalho nocivos à saúde, à alimentação adequada na quantidade e qualidade, a habitação higiênica, a recreação também estão nos seus cuidados, possibilitando ao trabalhador a conservação da saúde ou a recuperação mais rápida das suas forças orgânicas e da sua capacidade de trabalho no caso de ser atingido por qualquer doença, fora mesmo de qualquer ligação com a profissão (citado em Almeida, 2004, p.188).

A própria Anna Beatriz Almeida (2004, p.188) afirma que, provavelmente, como o artigo foi publicado sem autoria e possuía um tom de propaganda, ele teria sido elaborado por algum profissional médico da própria companhia mineradora. Em todo caso, temos essa referência que nos leva a inferir que, muitas vezes, não era do conhecimento das autoridades o que se passava no interior da mina e que a denúncia feita pelos mineiros correspondia ao que realmente ali ocorria naqueles anos, embora em alguns veículos, como a Revista Médica do Trabalho, ela estivesse sendo citada como exemplo de avanço nas questões relativas à saúde do trabalhador.

\section{Considerações finais}

O processo identitário entre esses operários se deu de diversos modos, principalmente quando a maioria parecia estar de acordo e bem consciente das terríveis condições de trabalho na mina nesse período e da necessidade de mudá-las. 
Não se pode dizer que esses operários estão conformados ou inconformados com a situação, mas sim que estão ao mesmo tempo conformados e inconformados: de um lado, acreditam-se impotentes para mudá-la e, em vez de assumir essa falta de força, confessar seu medo e tratar de superá-lo, muitos preferem tomar uma atitude fatalista e manifestar receio dos militantes que pretendem tirá-los dessa inatividade; de outro lado, apesar da calma aparente, há um inconformismo profundo, que às vezes é difícil perceber sob a capa do fatalismo. Até onde possam ir na ação, depende da repressão e da persistência do medo. Portanto, é errôneo tomar a 'despolitização' como um dado, pois pode desaparecer de um momento para outro (Chaui, 1981, p.71-74; destaque no original).

Tanto é que o inconformismo daqueles operários aparecia em outras ações que não a militância objetiva e partidária, política, dentro do sindicato. Emergia dos comportamentos, dos gestos, das falas, das inúmeras "maneiras de fazer", em que ficava marcada a força do inconformismo em relação à empresa e aos ingleses: "Eu nunca gostei deles!", era o que sempre dizia o senhor Waldir dos Santos, tomado por um sentimento de ódio profundo, de amarga revolta. Tema para outro artigo.

\section{AGRADECIMENTOS}

Agradeço a colaboração de minha bolsista de iniciação científica Marcela Martins (Programa Institucional de Bolsas de Iniciação Científicas/Universidade Federal do Rio de Janeiro [UFRJ]) e de Thiago Herzog (Programa de Pós-graduação em História/UFRJ), que me auxiliaram na revisão do texto para adequação às sugestões contidas nos pareceres.

\section{NOTAS}

${ }^{1}$ As condições de trabalho na mina de Morro Velho não eram diferentes das encontradas em outras minerações de propriedade de ingleses no Brasil, como pode ser muito bem visto na tese de Rafael de Freitas Souza (2007) sobre a mina de Passagem de Mariana, também em Minas Gerais, e em outros países do mundo; no caso da América Latina, pode ser verificado em trabalhos como os de Marshall Eakin $(1985,1986,1989)$. Para saber mais sobre a atuação dos ingleses no Brasil e em outros países, ver também Mayo $(1979,1981,1985,1986)$; Mayo, Coliver (1998); Randall (1972, 1985); Tenenbaum, McElveen (2000).

${ }^{2}$ Este artigo é resultado de uma pesquisa realizada quando da elaboração de minha dissertação de mestrado, defendida já há alguns anos, no Programa de Pós-graduação da Universidade Federal de Minas Gerais (UFMG), mas nunca publicada, intitulada Memória e cotidiano operário: Nova Lima no tempo de Vargas. Para escrevê-lo, retomei algumas entrevistas de história de vida realizadas com antigos operários da mina.

${ }^{3}$ Em artigo anterior, intitulado "Cultura e cotidiano nas minas de ouro: trabalhadores em tempos de experiências autoritárias e suas resistências plurais" (Maia, 2011), foco o segundo aspecto.

${ }^{4}$ Para um histórico detalhado e preciso sobre as doenças do mundo do trabalho, é imprescindível a leitura de Almeida $(1994,2004)$. De igual relevância para o conhecimento da história das doenças, é o trabalho de Nascimento e Carvalho (2004).

${ }^{5}$ Entrevista de pesquisa realizada pela autora em maio de 1996.

${ }^{6}$ Entrevista de pesquisa realizada pela autora em fevereiro de 1997.

${ }^{7}$ Entrevista de pesquisa realizada pela autora em maio de 1996.

8 "Recebem o nome de choco as pedras que, no estilhaçamento da rocha, desintegram-se do filão, mas não caem. Pesam toneladas. Por se encontrarem um tanto soltas, seu desabamento constitui uma ameaça à vida do mineiro. Não são pedras que se desprendem dos lados do realce, e sim da parte do teto, após a explosão do dinamite. Para soltá-las, emprega-se uma alavanca de aço, de 3 a 4 metros de altura, forçando o choco a cair. O nome provém do barulho surdo e seco que sua queda provoca, ao invés de tinir como as demais pedras, após o 'fogo' (explosão)" (Grossi, 1980, p.54). 
${ }^{9}$ A silicose é uma doença que, como a tuberculose, vai ulcerando os pulmões com microscópicas partículas de sílica, substância encontrada no minério que é aspirada por todos aqueles que trabalham na extração e redução do minério.

${ }^{10}$ Entrevista realizada pela autora com o senhor Waldir em maio de 1996.

${ }^{11}$ Entrevista realizada pela autora em fevereiro de 1997.

12 Entrevista realizada pela autora em maio de 1996.

${ }^{13}$ Sobre essa discussão da fábrica enquanto convento, no caso do Brasil, é importante a análise feita por Giroletti (1991). No livro, o autor trabalha com a segunda metade do século XIX, em Minas Gerais, em seus múltiplos aspectos econômicos políticos e culturais, para interpretar o sistema de fábrica então existente, utilizando, em determinados momentos, a perspectiva foucaultiana da " microfísica do poder" (Foucault, 1979).

${ }^{14}$ Entrevista realizada pela autora em fevereiro de 1997.

${ }^{15}$ Entrevista realizada pela autora com o senhor Waldir em maio de 1996.

${ }^{16}$ Entrevista realizada pela autora em fevereiro de 1997.

${ }^{17}$ A entrevista analisada por Le Ven (1998) é entrecortada pela tosse do operário Dazinho, com dificuldades de respirar devido à doença. Também o senhor Gentil, nosso entrevistado, em 1996, sofria do mesmo mal.

\section{REFERÊNCIAS}

ALMEIDA, Anna Beatriz de Sá.

As parcelas (in)visíveis da saúde do anônimo trabalhador: uma contribuição à história da medicina do trabalho no Brasil. (1920-1950). Tese (Doutorado em História) - Universidade Federal Fluminense, Niterói. 2004.

ALMEIDA, Anna Beatriz de Sá.

De moléstia do trabalho a doença profissional: contribuição ao estudo das doenças do trabalho no Brasil. Dissertação (Mestrado em História) Universidade Federal Fluminense, Niterói. 1994.

CERTEAU, Michel de.

A invenção do cotidiano. Petrópolis: Vozes. 1994.

CHAUI, Marilena.

Cultura e democracia. O discurso competente e outras falas. São Paulo: Moderna. 1981.

COSTA, Roberto C.

A cortina de ouro (Morro Velho). Belo Horizonte: Santa Maria. 1955.

EAKIN, Marshall.

British enterprise in Brazil: the St. John D'el Rey Mining Company and the Morro Velho mine, 1830-1960. Durham: Duke University Press. 1989.

EAKIN, Marshall.

Business imperialism and British enterprise in Brazil: the St. John d'el Rey Mining Company, Limited, 1830-1960. Hispanic American Historical Review, v.66, n.4, p.697-741. 1986.

EAKIN, Marshall.

The role of British Capital in the development of Brazilian gold mining. In: Greaves, Thomas; Culver, William (Ed.). Miners and mining in the
Americas. Manchester: Manchester University Press. p.11-30. 1985.

FERREIRA, Jorge.

Trabalhadores do Brasil: o imaginário popular (1930-1945). Rio de Janeiro: FGV. 1997.

FERREIRA, Marieta de Moraes.

Usos e abusos da história oral. Rio de Janeiro: FGV. 2001.

FOUCAULT, Michel.

Vigiar e punir: história da violência nas prisões. Petrópolis: Vozes. 1995.

FOUCAULT, Michel.

Microfísica do poder. Rio de Janeiro: Graal. 1979.

GIROLETTI, Domingos.

Fábrica convento disciplina. Belo Horizonte: Imprensa Oficial. 1991.

GROSSI, Yonne de Souza.

Mina de Morro Velho: a extração do homem - uma história de experiência operária. Rio de Janeiro: Paz e Terra. 1981a.

GROSSI, Yonne de Souza.

Movimento operário na mina de Morro Velho: política e classe. Dissertação (Mestrado em Ciência Política) - Faculdade de Filosofia e Ciências Humanas, Universidade Federal de Minas Gerais, Belo Horizonte. 1981b.

LE VEN, Michel Marie.

Dazinho: um cristão nas minas. Belo Horizonte: CDI. 1998.

LEVINE, Robert.

As classes urbanas no Brasil e o legado da década de 1930. In: A Revolução de 30. Seminário 
Internacional. CPDOC, Rio de Janeiro, set. 1980. Brasília: Editora da UnB. 1983.

MAIA, Andréa Casa Nova.

Cultura e cotidiano nas minas de ouro: trabalhadores em tempos de experiências autoritárias e suas resistências plurais. Topoi, v.12, n.22, p.209-227. 2011.

MAYO, John.

British merchants and Chilean development, 18511889. Boulder: Westview. 1986.

MAYO, John.

Commerce, credit and control in Chilean copper mining before 1880. In: Greaves, Thomas;

Culver, William (Ed.). Miners and mining in the Americas. Manchester: Manchester University Press. p.29-48. 1985.

MAYO, John.

Britain and Chile, 1851-1886: anatomy of a relationship. Journal of Interamerican Studies and World Affairs, v.23, n.1, p.95-120. 1981.

MAYO, John.

Before the nitrate era: British commission houses and the Chilean economy, 1851-1880. Journal of Latin American Studies, v.11, n.2, p.283-302. 1979.

MAYO, John; COLIVER, Simon.

Mining in Chile's Norte Chico: journal of Charles Lambert, 1825-1830. Boulder: Westview. 1998.

NASCIMENTO, Dilene; CARVALHO, Diana Maul de (Org.).

Uma história brasileira das doenças. Brasília:

Paralelo 15. v.1. 2004.
O DEBATE.

O Debate, maio 1934.

PIRES, Adriana et al.

Morro Velho: história, fatos e feitos. Nova Lima: Mineração Morro Velho. 1995.

RANDALL, Robert W.

British company and Mexican community: the English at Real del Monte, 1824-1849. Business History Review, v.59, n.4, p.622-644. 1985.

RANDALL, Robert W.

Real del Monte: a British mining venture in Mexico. Austin: Texas University Press. 1972.

SERVIÇO...

Serviço Médico da Divisão do Fomento da Produção Mineral. Relatório. Observador Econômico, n.9, p.68. 1943.

SOUZA, Rafael de Freitas.

Trabalho e cotidiano na mineração aurífera inglesa em Minas Gerais: a Mina de Passagem em Mariana (1863-1927). Tese (Doutorado em História Social) - Universidade de São Paulo, São Paulo. 2007.

TENENBAUM, Barbara A.; McELVEEN, James N. From speculative to substantive boom: the British in Mexico, 1821-1911. In: Marshall, Oliver (Ed.). English speaking communities in Latin America. London: Macmillan. p.51-79. 2000. 